\title{
Higher late summer methane emission from central than northern European lakes
}

\author{
Päivi RINTA, ${ }^{1 *}$ David BASTVIKEN,${ }^{2}$ Jos SCHILDER,,${ }^{1}$ Maarten VAN HARDENBROEK,,${ }^{1}$ Tabea STÖTTER, ${ }^{1}$ \\ Oliver HEIRI ${ }^{1}$
}

${ }^{1}$ Institute of Plant Sciences and Oeschger Centre for Climate Change Research, University of Bern, Altenbergrain 21, CH-3013 Bern, Switzerland; ${ }^{2}$ Department of Thematic Studies - Environmental Change, Linköping University, 58183 Linköping, Sweden

*Corresponding author: paivi.rinta@gmail.com

\begin{abstract}
Quantifying methane $\left(\mathrm{CH}_{4}\right)$ emissions from lakes is important for regional and global greenhouse gas emission inventories. However, regional and global estimates suffer from methodologically inconsistent data sets and from the situation that systematic flux measurements are presently available only for some regions in the world. In particular, many temperate regions dominated by agricultural land use, like central Europe, lack regional multi-lake studies of lacustrine $\mathrm{CH}_{4}$ emissions. We compare estimates of diffusive and ebullitive flux from 30 small central European and 17 small boreal lakes based on standardized measurements during a single visit per lake in late summer. Furthermore, we assess the amount of $\mathrm{CH}_{4}$ accumulated in the hypoxic deep-water layers in late summer. This provides an estimate of the potential release of $\mathrm{CH}_{4}$ from these lakes during autumn mixing (storage flux). The results show that emissions per unit area of lake surface from central European lakes are significantly higher than those from boreal lakes, with average estimates of diffusive and ebullitive flux being as much as six and 27 times higher, respectively. $\mathrm{CH}_{4}$ concentration in the surface water was significantly related with lake area and maximum depth in the boreal lakes. However, no significant relationships between diffusive and ebullitive fluxes and lake basin morphometry were found in central European or boreal lakes, as proposed in earlier studies, although the short measurement period $(6 \mathrm{~h}$ ) may not have been adequate for reliably quantifying ebullition in our study. As expected, storage flux was related to relative depth and relative volume of the hypoxic water layer in both regions. We discuss the relevance of the higher observed diffusive and ebullitive fluxes for regional estimates in central Europe based on an example of previous emission estimates from small lakes in Switzerland. Our results suggest that diffusive and ebullitive $\mathrm{CH}_{4}$ emissions from these lakes may be considerably higher than estimated based on widely applied relationships for predicting lacustrine $\mathrm{CH}_{4}$ emissions developed in northern European and North American regions. The results also confirm that modifications are necessary when applying these relationships to central European lakes. Our study highlights the inter-regional variability in lacustrine $\mathrm{CH}_{4}$ emissions and the need for regionally developed calibration data for validating and developing predictive models for estimating $\mathrm{CH}_{4}$ emissions from lakes at the landscape scale.
\end{abstract}

Key words: Greenhouse gases; methane; ebullition; diffusive flux; temperate lakes; upscaling.

Received: March 2016. Accepted: August 2016.

\section{INTRODUCTION}

Methane $\left(\mathrm{CH}_{4}\right)$ is an important greenhouse gas, accounting for approximately $20 \%$ of the radiative forcing by well-mixed greenhouse gases (Myhre et al., 2013). Freshwaters including lakes, reservoirs, streams, and rivers, are estimated to contribute 12 to $18 \%$ of the natural $\mathrm{CH}_{4}$ sources to the atmosphere (Kirschke et al., 2013). Quantifying these natural greenhouse gas emissions is important for understanding the mechanisms controlling atmospheric $\mathrm{CH}_{4}$ concentrations on decadal to millennial time scales (Loulergue et al., 2008; Kirschke et al., 2013; Nisbet et al., 2014). Furthermore, inventories of emissions are also needed at the regional and local scale to support national greenhouse gas management strategies (Ciais et al., 2014). However, large uncertainties are involved in the estimates of global $\mathrm{CH}_{4}$ emissions from freshwaters due to scarce measurements and inconsistent methodology in available data sets (Schulze et al., 2010; Bastviken et al., 2011; Holgerson and Raymond, 2016). Furthermore, while lakes in some regions have been intensively studied, some other lake types have received little attention in global and regional studies. For example, small lakes in the heavily populated temperate zone are understudied regarding their role as a source of $\mathrm{CH}_{4}$ (Bastviken et al., 2011; Ortiz-Llorente and Alvarez-Cobelas, 2012). Even though the total area of lakes in these regions is lower than, for example, in the boreal zone (Verpoorter $e t$ al., 2014), anthropogenic pressures on these lakes (e.g., eutrophication or organic pollution) may strongly affect their carbon cycles (Juutinen et al., 2009; Schrier-Uijl et al., 2011) and make them relevant for estimates of regional and global $\mathrm{CH}_{4}$ emissions.

Due to the lack of regional multi-lake studies of lacustrine $\mathrm{CH}_{4}$ emissions in many regions of the world, flux estimates in the better studied boreal zone have been used as a basis for upscaling emissions in other regions (Bastviken et al., 2004; Saarnio et al., 2009; Schulze et 
al., 2010; Hiller et al., 2014). For example, in the recent inventory of anthropogenic and natural $\mathrm{CH}_{4}$ emissions in Switzerland (Hiller et al., 2014), lacustrine $\mathrm{CH}_{4}$ emissions were estimated based on regression equations developed by Bastviken et al. (2004). These authors analysed $\mathrm{CH}_{4}$ flux data, predominantly measured during the summer period, from 73 lakes situated mainly in boreal northern Europe and continental northern temperate North America, with only few sites included from central Europe. The study concluded that the different components of openwater $\mathrm{CH}_{4}$ emissions can be predicted for the studied lakes based on lake surface area. However, Bastviken et al. (2004) and several other authors (Huttunen et al., 2003; Juutinen et al., 2009; Duc et al., 2010; Marotta et al., 2014; Rasilo et al., 2014; Yvon-Durocher et al., 2014; Yang et al., 2015) have pointed out that additional variables, such as lake productivity and temperature, are expected to strongly affect lacustrine $\mathrm{CH}_{4}$ emissions. Higher emissions in heavily populated central Europe compared with the regions mainly covered by the data set of Bastviken et al. (2004) were anticipated in the Swiss $\mathrm{CH}_{4}$ inventory (Hiller et al., 2014). Based on the restricted $\mathrm{CH}_{4}$ emission data available for Swiss lakes, Hiller et al. (2014) estimated that the emissions per unit area of lake surface from small Swiss lakes are three times higher than based on the equations by Bastviken et al. (2004). Hiller et al. (2014) emphasized that this represents a coarse estimate and point out that more calibration data are needed to validate this assumption. However, so far no multi-lake studies are available to confirm this assumed difference between $\mathrm{CH}_{4}$ emissions from lakes located in densely populated central Europe and the lakes from northern Europe or North America studied by Bastviken et al. (2004).

Recently, Schilder et al. (2013) and Rinta et al. (2015) studied diffusive $\mathrm{CH}_{4}$ fluxes and concentrations in different parts of the water column in 32 small lakes in central and western Europe and Fennoscandia and observed clear differences between the regions. Schilder et al. (2013) focused on describing within-lake patterns of diffusion but also noted that diffusive fluxes were apparently higher in central and western European lakes than in Fennoscandian lakes. However, the authors did not discuss the implications of these measurements for regional upscaling. Rinta et al. (2015) measured higher $\mathrm{CH}_{4}$ concentrations in the surface water of central and western European lakes confirming systematic differences in $\mathrm{CH}_{4}$ cycling between the two regions. However, the relatively small number of nonFennoscandian lakes in these studies did not allow a rigorous assessment of the extent to which diffusive $\mathrm{CH}_{4}$ fluxes differ between lakes in western and central Europe compared with Fennoscandian lakes. Furthermore, it remains unclear if the higher diffusive $\mathrm{CH}_{4}$ flux and $\mathrm{CH}_{4}$ concentrations in the surface water of western and central European lakes reported by these studies are also indica- tive for other $\mathrm{CH}_{4}$ emission pathways. In previous studies (Bastviken et al., 2004; Wik et al., 2016b), open-water $\mathrm{CH}_{4}$ emissions have been separated into diffusive flux, ebullition, and storage flux. The latter represents the $\mathrm{CH}_{4}$ that is accumulated under ice cover or in the hypoxic deep-water layers and can potentially be released to the atmosphere during ice melt or water column mixing (Encinas Fernández, et al., 2014; Ducharme-Riel et al., 2015). The fourth potential emission pathway, not examined in the present study, consists of plant-mediated flux from littoral zones with emergent vegetation (Juutinen et al., 2003).

Here we provide a detailed assessment of open water $\mathrm{CH}_{4}$ flux from the 32 lakes studied by Schilder et al. (2013) and Rinta et al. (2015) and from an additional 15 lakes in central Europe. For each lake, $\mathrm{CH}_{4}$ concentration and flux were measured during a single sampling visit in late summer. We used a consistent methodology to separate different open-water flux components, including diffusive flux, ebullition, and the potential storage flux released from these lakes during autumn overturning. Since we measured diffusive flux and ebullition in both shallow and pelagic zones of the lake basins, we can provide upscaled estimates accounting for the relative importance of these two zones in individual lakes (Schilder et al., 2013). This large data set allows us to assess if and to what extent 1) the magnitude of open-water $\mathrm{CH}_{4}$ flux and 2) the environmental variables related to different flux components differ between western and central European lakes and boreal lakes in late summer. In addition, we examine how the observed differences affect regional $\mathrm{CH}_{4}$ emission estimates from small lakes in central and western Europe. We assessed, as an example, how our revised flux estimates from central European lakes potentially influence the approach used to assess $\mathrm{CH}_{4}$ emissions from Swiss lakes in the $\mathrm{CH}_{4}$ emission inventory of Hiller et al. (2014).

\section{METHODS}

\section{Study sites}

Data from a total of 47 small lakes in Europe are available for this study (Fig. 1, Supplementary Tab. 1). Seventeen of these lakes are located in the boreal/hemiboreal zone in southern Finland and Sweden (referred to as boreal lakes). They are situated on non-calcareous Precambrian bedrock covered by Quaternary deposits and generally characterized by humic water with a naturally low pH (Supplementary Tab. 2). Two Swedish lakes (Hargsjön and Illersjön) are exceptions as they are situated on alkaline carbonate-rich soils. The Swedish lakes were studied in August and September 2010 and the Finnish lakes in August 2011. Thirty of the studied lakes are situated in western and central Europe (here referred to as central European lakes). They are located in lowland or 
subalpine regions dominated by agriculture or grasslands in the Netherlands, Germany, and Switzerland. The lakes are located on mainly calcareous sedimentary bedrock or Quaternary deposits. The Dutch, German and 10 of the
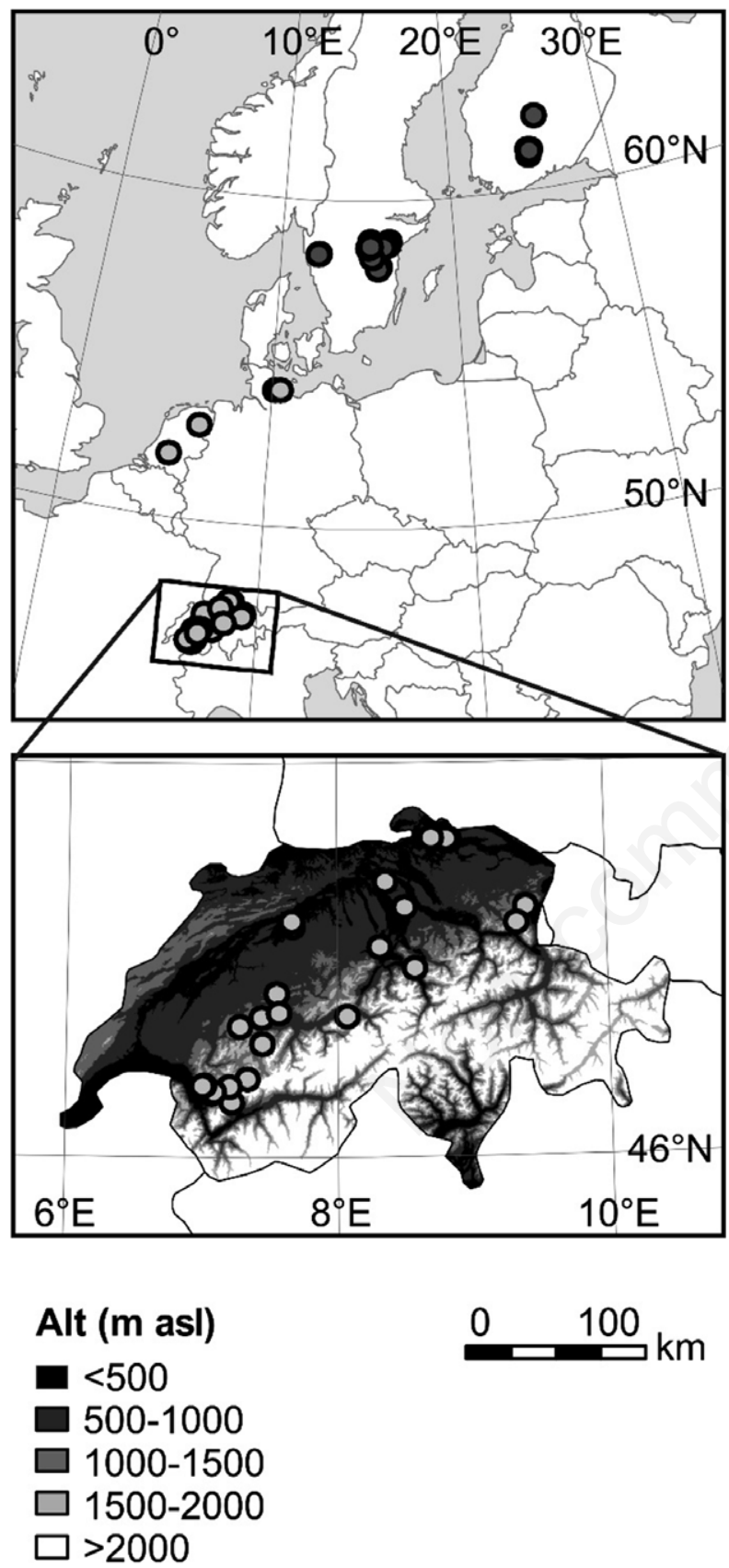

Fig. 1. Geographical location of the 47 study lakes. In the upper figure, dark grey symbols indicate boreal lakes $(n=17)$ and light grey symbols indicate central European lakes $(n=30)$. Source of digital elevation model: Swiss Federal Office of Topography (2005).
Swiss lakes were studied in August and September 2011. $\mathrm{CH}_{4}$ concentration and diffusive flux measurements from these and the Fennoscandian lakes are described in detail in Schilder et al. (2013) and Rinta et al. (2015). Fifteen additional Swiss lakes were sampled in August 2012.

\section{Gas sampling and flux measurements}

The field sampling was conducted at each lake during a single day in late summer. For the analysis of $\mathrm{CH}_{4}$ concentrations in water, samples from the surface water (ca. $0.5 \mathrm{~m}$ below the surface) and from the bottom water (ca. 0.5-1 m above the sediment) were collected using a $5 \mathrm{~L}$ water sampler (Uwitec, Austria) in the deepest part of the basin. Sampling and storage of gas samples in acidified $\mathrm{N}_{2}$-filled glass vials are described in detail in Rinta et al. (2015).

The ebullition and diffusive flux components were estimated using the floating chamber design and methodology described by Bastviken et al. (2004; 2010). Four groups of three chambers were deployed for approximately $6 \mathrm{~h}$ (ca. 10 a.m. - 4 p.m.) on a transect from the near-shore zone to the central part of the lake (see Schilder et al., 2013 for details). After $6 \mathrm{~h}, 30 \mathrm{ml}$ gas were taken from each chamber with a syringe and injected into a glass vial (10 mm thick butyl rubber stopper; Apodan, Denmark) or into a $10 \mathrm{ml}$ exetainer (Labco Limited, UK) prefilled with saturated $\mathrm{NaCl}$ solution. The exetainers were stored upside down with a small amount of $\mathrm{NaCl}$ solution covering the septa. Samples for determining $\mathrm{CH}_{4}$ concentration in the surface water and in the ambient air were collected at each group of chambers following Bastviken et al. (2010).

$\mathrm{CH}_{4}$ concentrations in the headspace of the storage vials were quantified using a GC-FID equipped with a methanizer (Agilent $6890 \mathrm{~N}$ with a PlotQ capillary column for the samples from the Finnish lakes, Shimadzu GC-2014 with a ShinCarbon ST column for the samples taken from the Swiss lakes in August 2012, and Shimadzu GC-8 with PoropackN column for the others). The analytical error $(\sigma)$ based on repeated measurements of standards $(n \geq 3)$ was less than $1.7 \%$.

\section{Concentration and flux calculations}

Concentrations of $\mathrm{CH}_{4}$ in the lake water were calculated using the headspace equilibration method (McAuliffe, 1971) by applying Henry's law describing gas-water partitioning (Stumm and Morgan, 1996; see methods in Bastviken et al., 2010). The total flux into the floating chambers, including both diffusion and ebullition, was estimated using simple flux calculation based on the accumulated $\mathrm{CH}_{4}$ divided by chamber area and time (Bastviken et al., 2010). Flux estimates were expressed per $\mathrm{m}^{2}$ and per day rather than per hour for comparison with values reported in the literature. The diffusive flux 
into the chambers was calculated based on measured $\mathrm{CH}_{4}$ concentration in the surface water, the calculated theoretical $\mathrm{CH}_{4}$ concentration in the surface water when in equilibrium with the $\mathrm{CH}_{4}$ partial pressure in the chamber, and the estimated piston velocity $(k)$. The $k$ value was estimated based on the $\mathrm{CH}_{4}$ accumulation in the chamber corrected for the chamber area, volume, and deployment duration and for the decreasing concentration gradient due to increasing $\mathrm{CH}_{4}$ concentration in the chamber as described by Bastviken et al. (2004). Chambers having received ebullition were eliminated from these calculations. They were identified based on having unrealistically high calculated $k$ values indicating that more $\mathrm{CH}_{4}$ entered the chamber than could be explained by diffusion only. This method is described in detail by Bastviken et al. (2004) and Schilder et al. (2013). In short, chambers returning $k$ values at a Schmidt number of $600\left(k_{600}\right.$; see definition in Bade, 2009) higher than the mixing depth of the water column, or $k_{600}$ values higher than 2.1 times the lowest $k_{600}$ within the group were considered to have received both diffusive flux and ebullition.

Chamber groups were classified into two zones based on water depth: chamber groups located in shallower water than the thermocline depth were defined as belonging to the shallow water zone and chamber groups in deeper water than the thermocline depth belonged to the pelagic zone. In six non-stratified lakes, all chamber groups were classified as belonging to the shallow water zone (Supplementary Tab. 3). In two lakes, the thermocline depth was so shallow that all chamber groups were defined as pelagic. This approach differs from the procedure of Schilder et al. (2013), who classified chamber groups for whole-lake upscaling of diffusive flux into near-shore and central areas based on the distance to the shoreline.

Average total flux into the chambers and average diffusive flux in the shallow and pelagic zone was calculated for each lake. Due to the high ebullition rates in some lakes, diffusive flux both in the shallow and pelagic zone could be separated only for 33 out of 47 lakes (Supplementary Tab. 3). To estimate the diffusive flux in the zones where no separation of diffusive and ebullitive flux was possible, we used the diffusive flux of the other zone if diffusive flux estimates were available. In two lakes where these were not available, we estimated the diffusive flux based on the wind speed and $\mathrm{CH}_{4}$ concentration in the surface water as described in Schilder et al. (2013). Local wind speed data for these two lakes were obtained from the nearest weather station (data downloaded from Swiss Federal Office of Meteorology and Climatology, https://gate.meteoswiss.ch/idaweb and from Royal Netherlands Meteorological Institute, http://www.knmi.nl /climatology/daily_data).

Ebullition was estimated by subtracting the average diffusive flux from the average total flux into the cham- bers in the respective zone. Due to the differences in methodology for calculating total flux and diffusive flux (total flux calculations do not take into account the decreasing concentration gradient due to increasing $\mathrm{CH}_{4}$ concentration in the chambers), subtraction returned negative values for ebullition in some cases. These negative ebullitive fluxes were corrected to 0 . Average estimates for total flux, diffusive flux, and ebullition for the entire lake surface were corrected for the fraction of shallow and pelagic zones of the lake surface area to produce wholelake estimates. The fractions of shallow and pelagic zones were calculated based on the thermocline depth and lake bathymetry (see below).

The dissolved $\mathrm{CH}_{4}$ that accumulated in the hypoxic deep-water layers during the summer and that was potentially released to the atmosphere during water column mixing in the autumn (referred to as storage flux) was estimated by multiplying the $\mathrm{CH}_{4}$ concentration in the bottom water by the volume of the hypoxic layer (see below).

\section{Environmental variables}

We explored relationships between $\mathrm{CH}_{4}$ fluxes and lake characteristics which have been identified as relevant for predicting $\mathrm{CH}_{4}$ emissions from lakes in earlier studies. These variables include lake morphology, relative volume of the hypoxic layer, temperature, dissolved organic carbon (DOC) concentration, and nutrient concentrations (Michmerhuizen et al., 1996; Bastviken et al., 2004; Juutinen et al., 2009; Schrier-Uijl et al., 2011; Ouellet et al., 2012; Kankaala et al., 2013; Rasilo et al., 2014).

Bathymetric maps were obtained from municipal or regional authorities or from the literature. They were digitized and the volumes of the whole lake, the hypolimnion, and the hypoxic water layer were calculated using the 3D Analyst tool in ArcMap 9.3 (Esri). The hypolimnion was defined as the water layer below the depth from the surface where the temperature gradient first reached $1{ }^{\circ} \mathrm{C} \mathrm{m}^{1}$ (Huotari et al., 2009) and the hypoxic water layer as below the depth were oxygen saturation first reaches hypoxic conditions (oxygen saturation $<5 \%$ ) in the temperature and oxygen profile created in the field (WTW, Oxi 1970i, Germany). Relative depth $\left(z_{r}\right)(\%)$ of the lake basin was calculated according to following equation (Wetzel, 2001):

$z_{r}=\frac{50 z_{m} \sqrt{\pi}}{\sqrt{A_{0}}}$

where $z_{m}$ is the maximum depth and $A_{0}$ the lake surface.

Estimates of mean annual and July air temperatures and precipitation for the closest weather station or interpolated for the lake location were obtained from national meteorological services for the reference period 19812010 (except for Switzerland 1981-2006) and land use in the catchment from the CORINNE Land Cover database 
(Nippel and Klingl, 1998; European Environmental Agency, 2007). Conductivity, $\mathrm{pH}$, total phosphorus (TP) and total nitrogen (TN) concentration, and absorbance at $420 \mathrm{~nm}$ as an indicator for coloured dissolved organic matter concentration were analysed as described in Rinta et al. (2015). Volume-weighted average nutrient conditions in the water column were calculated based on the $\mathrm{TN}$ and TP concentration in the bottom water and in the surface water and corresponding hypolimnion and mixing layer volumes.

\section{Numerical analyses}

Statistical analyses of $\mathrm{CH}_{4}$ concentrations, fluxes, and environmental variables were made using $\mathrm{R}$ ( $\mathrm{R}$ Core Team, 2013). Each variable was tested for normal distribution using the Shapiro-Wilk test, and skewed distributions were $\log _{10}$-transformed. All reported averages of concentration and flux data represent back-transformed values of averages calculated on $\log _{10}$-transformed data (marked using term "log-average"). Statistically significant differences between the regions were detected using Student's $t$-test and a simple linear regression model was used to examine relationships between variables. When examining relationships between $\mathrm{CH}_{4}$ concentrations or emissions and environmental variables, $\mathrm{p}$-values were adjusted for multiple testing according to the FDR method (Benjamini and Hochberg, 1995) within the sub-data sets separated by region and flux component.

\section{Influence on lacustrine $\mathrm{CH}_{4}$ emission estimates from Switzerland}

For assessing the relevance of our $\mathrm{CH}_{4}$ flux measurements in central European lakes for regional upscaling, we compared emission estimates from small Swiss lakes: i) based on the area-dependent regression equations by Bastviken et al. (2004) as described in the original publication; ii) based on the area-dependent regression equations by Bastviken et al. (2004) as modified for the Swiss $\mathrm{CH}_{4}$ inventory (Hiller et al., 2014); and iii) based on areadependent regressions we developed by following the methodology of Bastviken et al. (2004) but using our new late-summer $\mathrm{CH}_{4}$ flux measurements from 30 central European lakes. For comparison, the regressions were developed for our boreal lakes as well.

For the estimation based on our measurements, we first extrapolated our flux measurements per $\mathrm{m}^{2}$ and day to emissions per lake and year following Bastviken et al. (2004). Annual emission estimates per lake were expressed in grams carbon rather than mols $\mathrm{CH}_{4}$ for comparison with values reported in the previous studies. Bastviken et al. (2004) extrapolated diffusive flux per day obtained from single or multiple measurements during the open-water period to flux per year by multiplying the val- ues by the number of ice-free days of each lake (90-150 ice-cover days per year). For estimating annual emissions from our studied lakes, we assumed that ice cover in lakes in southern Finland lasts for 150 days (Korhonen, 2005), in southern and central Sweden 110 days (Swedish Meteorological and Hydrological Institute, 2014), and in Switzerland above $1500 \mathrm{~m}$ asl for six months (Guthruf et al., 1999). In central European lowland lakes, we assumed no ice cover, since in Swiss lowland lakes permanent ice cover only develops during cold winters (Guthruf et al., 1999). Following Hiller et al. (2014), ebullition was assumed to occur during the warmest half of the year only.

Based on the annual emission estimates per lake, we then calculated regression equations using the linear model function ( $1 \mathrm{~m})$ in R (R Core Team, 2013) for $\log _{10^{-}}$ transformed area and emission data. Equations for ebullition were calculated excluding the zero values. Due to the sporadic nature of ebullition in lakes, it can be expected that a longer measurement period than possible in our campaign would have revealed ebullition in most lakes. For calculating equations for the storage emission, we replaced zero values by $1\left(\log _{10}\right.$-transformed 0$)$. As a last step, the regression equations were used to estimate emissions from small Swiss lakes in the size range of 0.5 to 75 ha. Following Hiller et al. (2014), we calculated ebullition only for lakes located lower than $1500 \mathrm{~m}$ asl. Distribution of lakes (including reservoirs and artificial ponds) in Switzerland, their surface areas, and altitudes were obtained from the Primary surface layer of the landscape model VECTOR25 (Swiss Federal Office of Topography, 2007) and from the digital elevation model of Switzerland (Swiss Federal Office of Topography, 2005). Hiller et al. (2014) did not apply correction factors for back-transformation bias of log-transformed data (Newman, 1993). We therefore also present uncorrected backtransformed values, since our aim was to compare how our $\mathrm{CH}_{4}$ emission estimates affect regional upscaling based on this earlier study. However, we do briefly report how much our estimates would have to be corrected as a consequence of back-transformation.

\section{RESULTS}

\section{Environmental conditions}

Environmental conditions in the two study regions, boreal Fennoscandia and central Europe, are clearly different (Tab. 1). Mean annual air temperature and precipitation as well as water temperature during the sampling were significantly higher in central Europe than in the boreal regions $(\mathrm{P}<0.001)$. Also, TN concentrations were significantly higher $(\mathrm{P}=0.03-0.04)$ and absorbance was lower for the central European lakes ( $\mathrm{P}=0.0003)$. Different geology is reflected in significantly different conductivity 
and $\mathrm{pH}$ in the surface water $(\mathrm{P}<0.0001)$. However, no significant difference in lake size (lake surface area, maximum depth), fraction of the hypoxic volume relative to the total volume (Supplementary Tab. 1), or TP concentrations was observed between the central European and boreal lakes of our data set $(\mathrm{P}=0.2-0.5)$.

\section{$\mathrm{CH}_{4}$ fluxes}

$\mathrm{CH}_{4}$ concentrations in the surface water varied between 0.1 and $17.6 \mu \mathrm{mol} \mathrm{L}^{-1}$ (Fig. 2a). They were significantly higher in the central European lakes than in the boreal lakes $(\mathrm{P}<0.0001)$. In the boreal lakes, log-average concentration in the surface water was $0.4 \mu \mathrm{mol} \mathrm{\textrm {L } ^ { - 1 }}$ (range 0.1-3.9 $\mu \mathrm{mol} \mathrm{L}^{-1}$ ) and in central European lakes $1.8 \mu \mathrm{mol} \mathrm{L}^{-1}$ (range 0.3-17.6 $\mu \mathrm{mol} \mathrm{L}^{-1}$ ).

In the boreal lakes, log-average total $\mathrm{CH}_{4}$ flux into the chambers in the shallow zone was $0.3 \mathrm{mmol} \mathrm{m}^{-2}$ day $^{-1}$ (range 0.02-2.0 $\mathrm{mmol} \mathrm{m}^{-2} \mathrm{day}^{-1}$ ) and in the pelagic zone $0.2 \mathrm{mmol}$ $\mathrm{m}^{-2}$ day $^{-1}$ (range 0.04-1.3 $\mathrm{mmol} \mathrm{m}^{-2}$ day $^{-1}$ ) (Fig. 3). In the central European lakes, log-average total $\mathrm{CH}_{4}$ flux into the chambers in the shallow zone was $3.6 \mathrm{mmol} \mathrm{m}^{-2}$ day $^{-1}$ (range $0.2-54.9 \mathrm{mmol} \mathrm{m}^{-2} \mathrm{day}^{-1}$ ) and in the pelagic zone $2.7 \mathrm{mmol}$ $\mathrm{m}^{-2}$ day $^{-1}$ (range 0.05-35.7 $\mathrm{mmol} \mathrm{m}^{-2}$ day $^{-1}$ ).

Zone-weighted diffusive and ebullitive fluxes were significantly higher in the central European lakes than in the boreal lakes $(\mathrm{P}<0.0001-0.002)$ (Fig. 2 b,c). These differences between the regions are not related to the lake size distribution, since they are still apparent when only the boreal lakes in the same range of surface areas as the central European lakes are examined $(\mathrm{P}<0.0001$ and $\mathrm{P}=0.01$, respectively). The log-average daily diffusive flux was six times higher in central European lakes than in boreal lakes. In the boreal lakes, it was $0.2 \mathrm{mmol} \mathrm{m}^{-2}$ day $^{-1}$ (range 0.02-1.3 mmol m may $^{-1}$ ) and in the central European lakes $1.2 \mathrm{mmol} \mathrm{m}^{-2}$ day $^{-1}$ (range 0.06-8.5 mmol $\mathrm{m}^{-2}$ day $^{-1}$ ). Diffusive flux was significantly related to $\mathrm{CH}_{4}$ concentrations in the surface water both in the boreal and the central European lakes $\left(\mathrm{P}=0.02, \mathrm{R}^{2}=0.33\right.$ and $\mathrm{P}<0.0001, \mathrm{R}^{2}=0.76$, respectively) (Fig. 4). The log-average daily ebullitive flux was 27 times higher in central European lakes than in boreal lakes. In the boreal lakes, it was $0.03 \mathrm{mmol} \mathrm{m}^{-2}$ day $^{-1}$ (range 0-1.8 $\mathrm{mmol} \mathrm{m}^{-2}$ day $^{-1}$ ) and in the central European lakes $0.8 \mathrm{mmol} \mathrm{m}^{-2}$ day $^{-1}$ (range 0-45.4 mmol m${ }^{-2}$ day $^{-1}$ ) (Fig. 2c). The storage flux did not differ significantly between the regions $(\mathrm{P}=0.1)$ (Fig. 2d). In the boreal lakes, the estimated storage flux varied from zero up to $11910 \mathrm{mmol} \mathrm{m}^{-2}$ and in the central European lakes up to $3476 \mathrm{mmol} \mathrm{m}^{-2}$.

\section{$\mathrm{CH}_{4}$ fluxes related to environmental variables}

Within each of the two study regions, we explored relationships between late summer $\mathrm{CH}_{4}$ concentration in the surface water and diffusive, ebullitive, and storage flux with the following environmental variables: lake area, maximum depth, relative depth, relative volume of the hypoxic water layer, mean annual air temperature, absorbance in the surface water, TN concentration in the surface water, and average TN concentration in the water column (Tab. 2). We tested only TN concentrations, since TN and TP concentrations were correlated both in the surface water $\left(\mathrm{P}<0.0001, \mathrm{R}^{2}=0.50\right)$ and in the water column $(\mathrm{P}<0.0001$, $\left.\mathrm{R}^{2}=0.60\right)$ in our data set. In addition, $\mathrm{TN}$ concentration in the surface water was more strongly related to the fraction of managed land (incl. agricultural land and artificial surfaces $)$ in the catchment $\left(\mathrm{P}<0.0001, \mathrm{R}^{2}=0.54\right)$.

Only $\mathrm{CH}_{4}$ concentration in the surface water and stor-

Tab. 1. Environmental characteristics of the study regions and water chemistry of the studied lakes.

\begin{tabular}{|c|c|c|c|c|c|}
\hline & & \multicolumn{2}{|c|}{ Boreal } & \multicolumn{2}{|c|}{ Central European } \\
\hline & & Mean & Range & Mean & Range \\
\hline Mean annual air temperature & ${ }^{\circ} \mathrm{C}$ & 5.6 & $3.2-6.9$ & 8.7 & $4.9-11.8$ \\
\hline Annual precipitation & $\mathrm{mm}$ & 695 & $620-902$ & 1506 & $742-2323$ \\
\hline Forests in the catchment & $\%$ & 76 & $23-100$ & 18 & $0-100$ \\
\hline Managed land in the catchment (incl. agricultural areas and artificial surfaces) & $\%$ & 13 & $0-58$ & 38 & $0-100$ \\
\hline Temperature of surface water & ${ }^{\circ} \mathrm{C}$ & 17 & $14-18$ & 20 & $11-25$ \\
\hline Conductivity of surface water & $\mu \mathrm{S} \mathrm{cm}^{-1}$ & 95 & $24-311$ & 256 & $54-462$ \\
\hline $\mathrm{pH}$ of surface water & & 6.6 & $5.4-7.8$ & 8.3 & $6.6-9.3$ \\
\hline Absorbance of surface water & at $420 \mathrm{~nm}$ & 0.045 & $0.006-0.104$ & 0.019 & $0.003-0.121$ \\
\hline $\mathrm{TP}$ in surface water & $\mu \mathrm{g} \mathrm{L}^{-1}$ & 19 & $3-45$ & 35 & $7-260$ \\
\hline Average TP in water column & $\mu \mathrm{g} \mathrm{L}^{-1}$ & 185 & $5-2247$ & 109 & $9-985$ \\
\hline $\mathrm{TN}$ in surface water & $\mu \mathrm{g} \mathrm{L}^{-1}$ & 585 & $200-1172$ & 949 & $290-2900$ \\
\hline Average TN in water column & $\mu \mathrm{g} \mathrm{L}^{-1}$ & 1259 & $250-6549$ & 1657 & $403-4137$ \\
\hline
\end{tabular}

$T P$, total phosphorus; $T N$, total nitrogen. 
age flux were significantly related to environmental variables in our data set (Tab. 2). $\mathrm{CH}_{4}$ concentration in the surface water was negatively related to lake area and maximum depth in boreal lakes. In the central European lakes, the relationships were not statistically significant. No significant relationships between diffusive flux or ebullition and environmental variables were found. Storage flux was related to morphological parameters (e.g., positively to relative depth and relative volume of the hypoxic water layer) and positively correlated with average TN concentration in the water column both in the boreal and in the central European lakes. a)

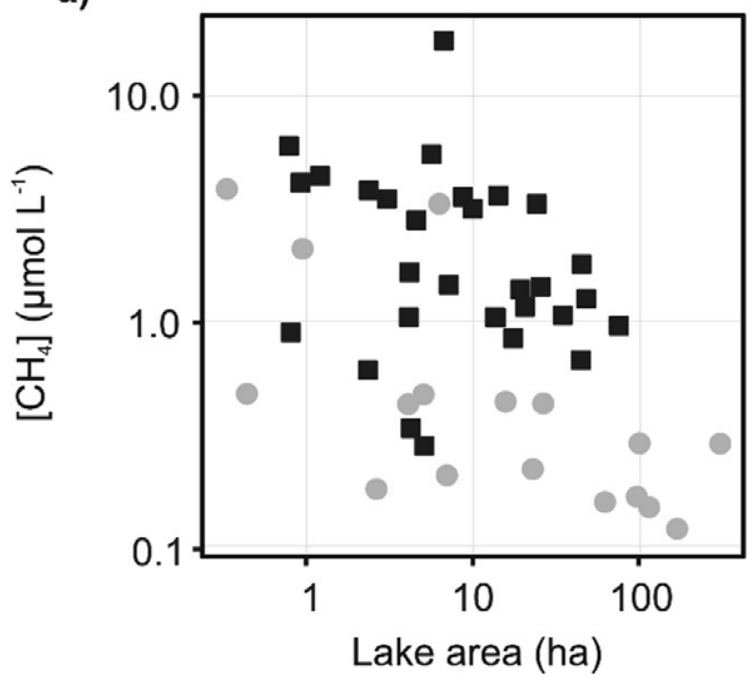

c)

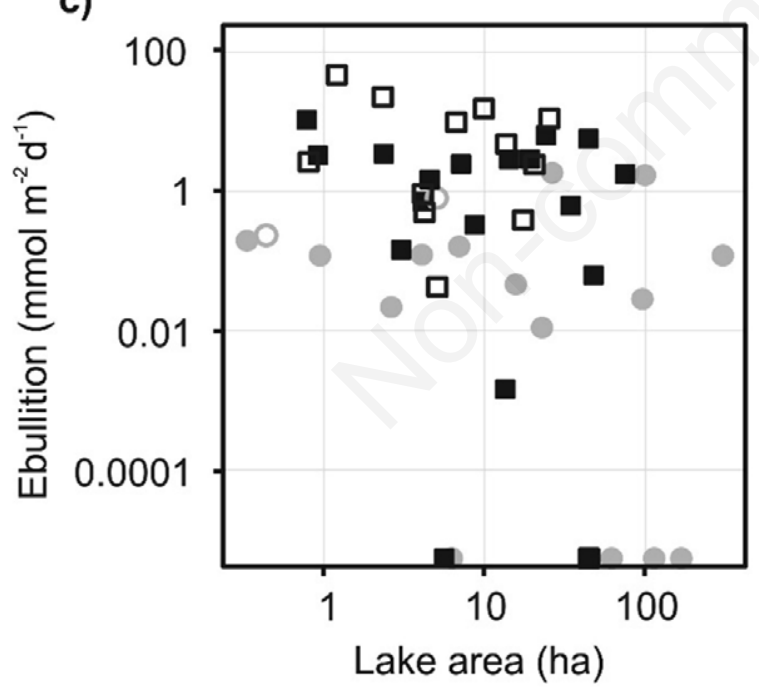

- Boreal

- Central European b)

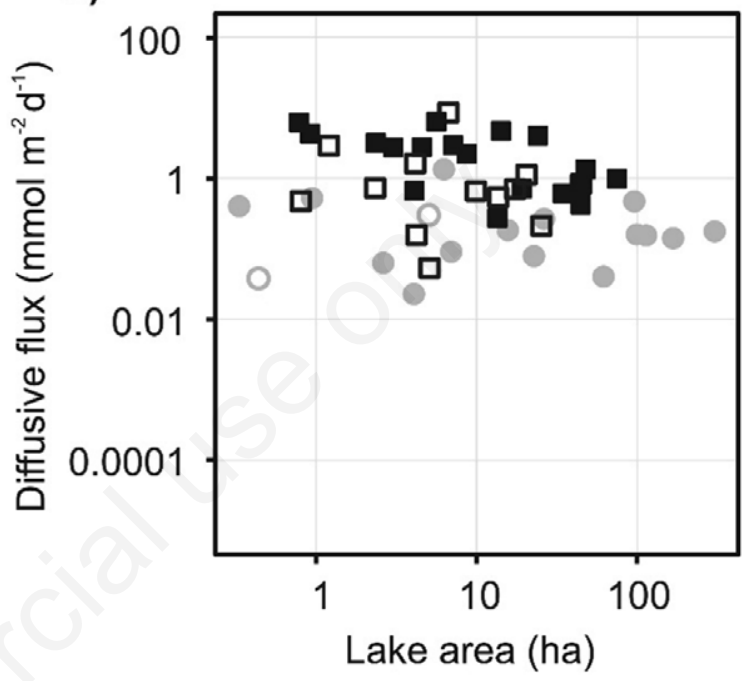

d)

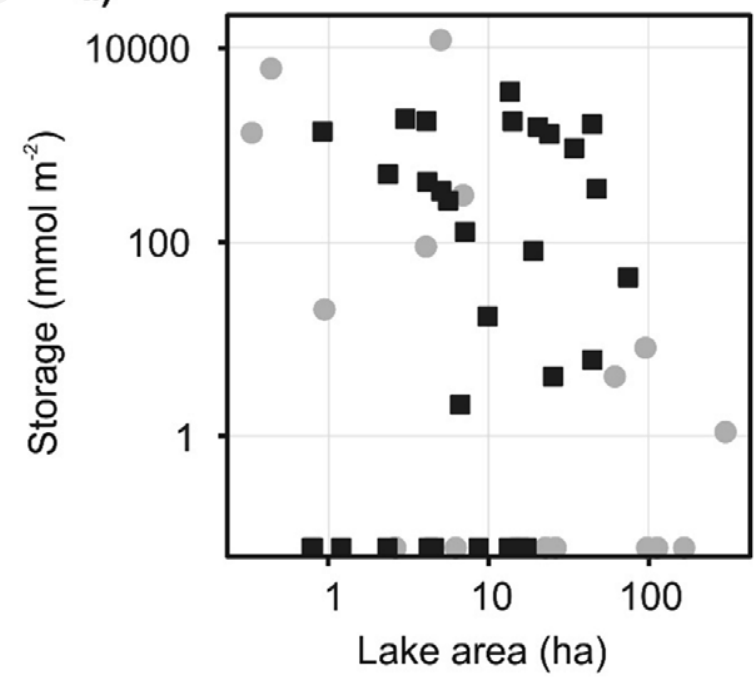

Figures $b$ and $c$

- Diffusive flux/ebullition measured

․ Diffusive flux/ebullition estimated

Fig. 2. a) $\mathrm{CH}_{4}$ concentration ([CH 4$\left.]\right)$ in the surface water, b) zone-weighted average diffusive flux, c) zone-weighted average ebullitive flux, and d) storage flux relative to lake area. In b and c, open symbols indicate lakes where separation of diffusive and ebullitive flux was not possible in all zones and values needed to be estimated based on diffusive flux in the other zone or based on $\left[\mathrm{CH}_{4}\right]$ in the surface water and wind speed (see Supplementary Tab. 3 for details). In c and d, values plotted on the x-axis represent zero values. 


\section{Influence on lacustrine $\mathrm{CH}_{4}$ emission estimates from Switzerland}

Annual diffusive, ebullitive, and storage emissions per lake based on our flux measurements in late summer relative to lake area are presented in Fig. 5. In boreal lakes, significant relationships were found between lake area and annual diffusive emission per lake and annual ebullition per lake (Tab. 3). In central European lakes, significant relationships were found between lake area and annual diffusive emission per lake and storage emission per lake. The relationship between lake area and annual ebullition per lake was nearly significant.

The total number of Swiss lakes in the size range of 0.5 to 75 ha is estimated to be 2161 , and they cover in total 8310 ha (Swiss Federal Office of Topography, 2007). Forty-five \% of the lakes in this size range were located higher than $1500 \mathrm{~m}$ asl. The original area-dependent regression equation by Bastviken et al. (2004) and the modified equation applied for the Swiss $\mathrm{CH}_{4}$ emission inventory of Hiller et al. (2014) (Fig. 5) return a total annual diffusive emission of 0.06 and $0.18 \mathrm{Gg}$ year $^{-1}$, ebul-

Tab. 2. Relationships of the environmental variables with $\mathrm{CH}_{4}$ concentration in the surface water and diffusive, ebullitive, and storage $\mathrm{CH}_{4}$ flux per unit area of lake surface.

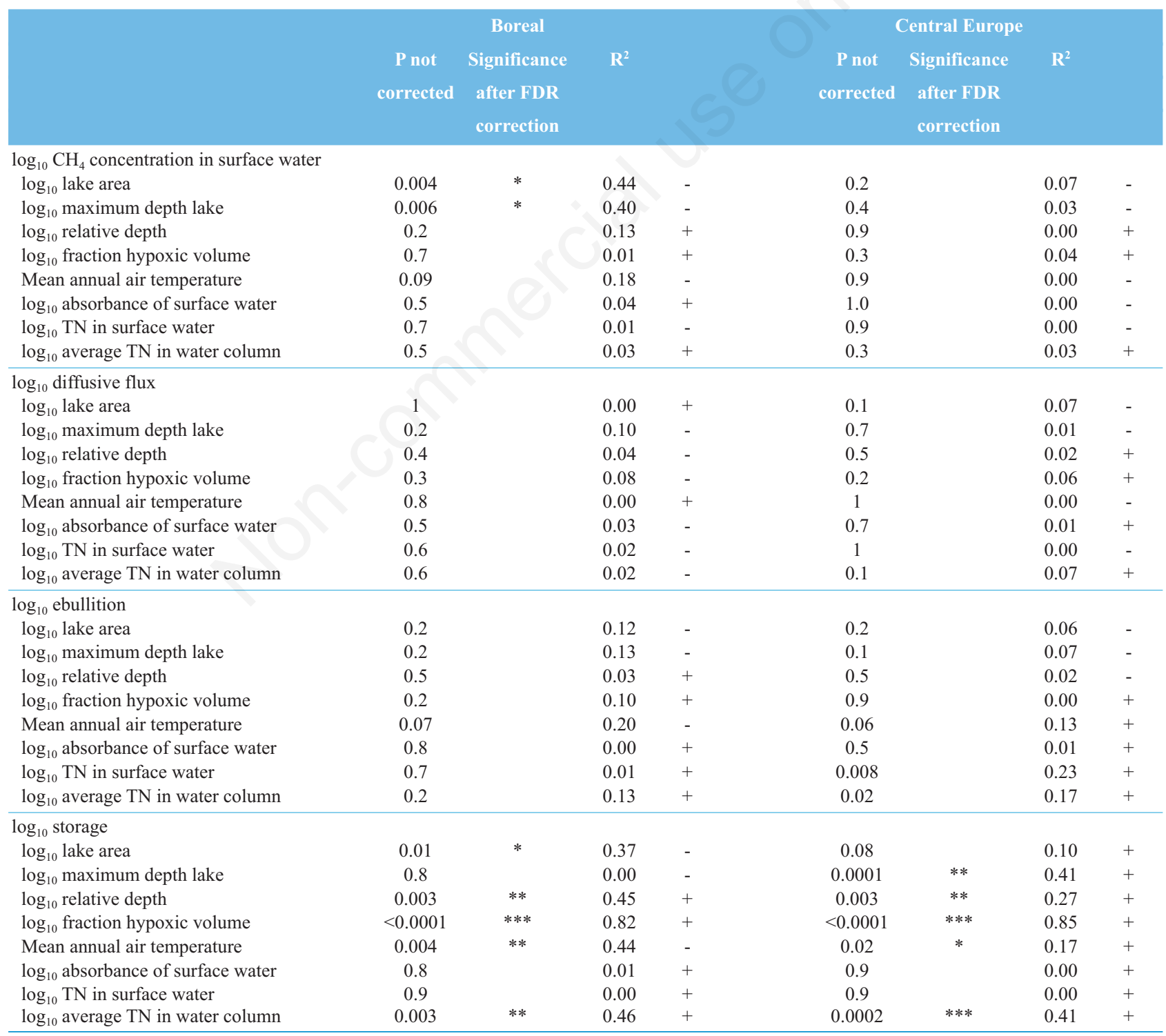

$P$-values represent uncorrected values, asterisks show the significance after correction for multiple testing using the false discovery rate method (FDR) by Benjamini and Hochberg (1995), $* * * P<0.001, * * P<0.01, * P<0.05)$. Negative or positive correlations are indicated by plus or minus symbols. 


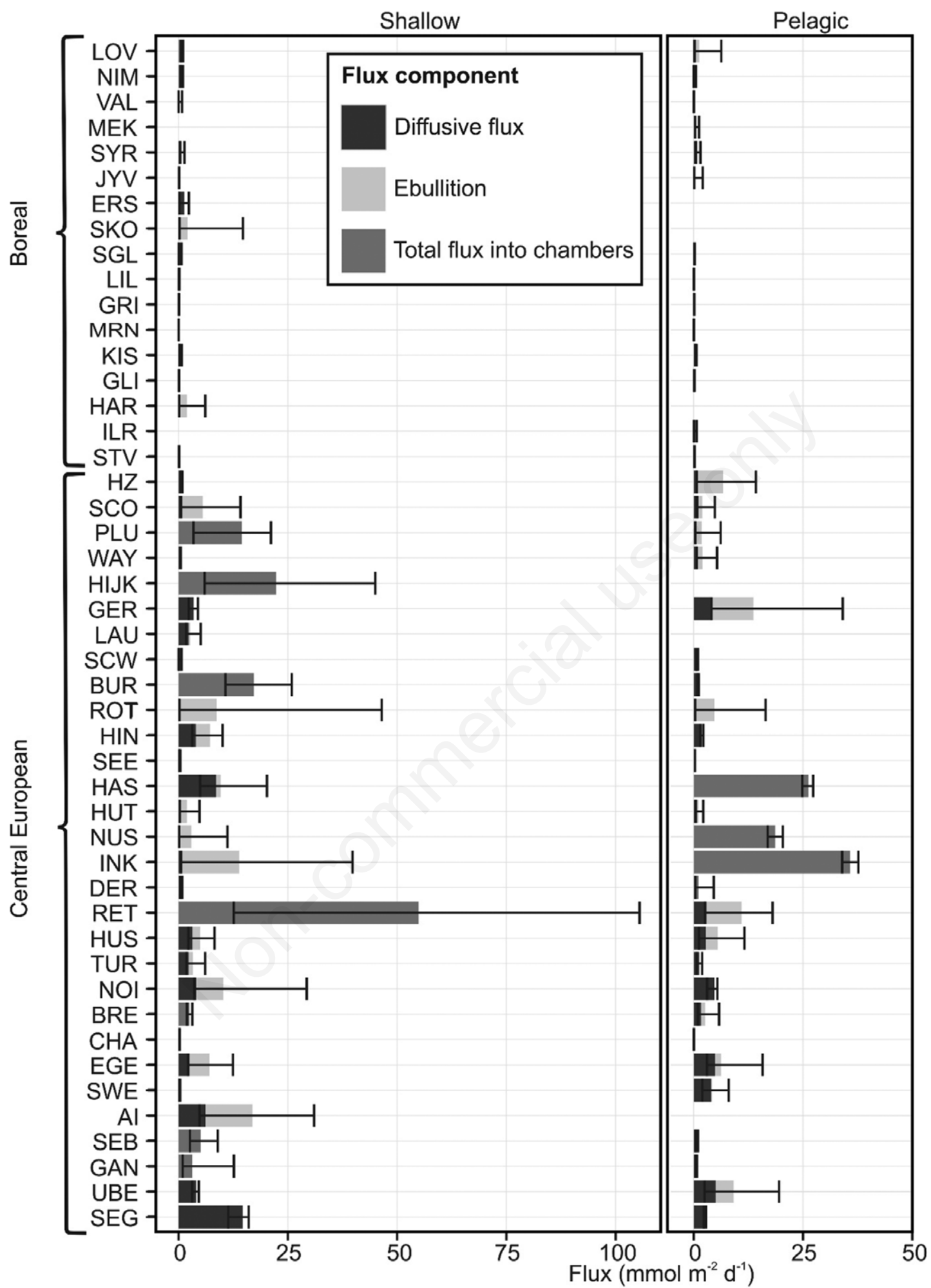

Fig. 3. Average open-water $\mathrm{CH}_{4}$ flux estimated from flux measurements during fieldwork in the shallow and pelagic zone of the studied lakes. Estimates are provided for diffusive (dark grey) and ebullitive flux (light grey) where it was possible to separate these two flux components (see text for details). In lakes where this was not possible (i.e., in lakes where all chambers within a given depth zone received ebullition), we provide total flux into chambers instead (medium grey). In some small lakes, all chamber groups were classified to the shallow or the pelagic zone and flux estimates for only one of these zones are provided (see Supplementary Tab. 3). Error bars show the range of the total flux in the chambers in the respective zone. 
litive emission of 0.11 and $0.17 \mathrm{Gg}$ year $^{-1}$, and storage emission of 0.06 and $0.17 \mathrm{Gg}_{\text {year }}{ }^{-1}$, respectively, from Swiss lakes in the given size range. The equations based on our measurements return a total annual diffusive emission of $0.35 \mathrm{Gg} \mathrm{C}$ year $^{-1}$ and ebullitive emission $0.16 \mathrm{Gg} \mathrm{C}$ year ${ }^{-1}$. Applying correction factors for backtransformation bias of log-transformed data $\left(10^{\varepsilon}\right.$; Newman, 1993) in our equations would have led to $40 \%$ higher total annual diffusive emission and more than $400 \%$ higher ebullitive emission for the estimates based on our measurements $\left(10^{\varepsilon}\right.$ values 1.4 and 2.7 , respectively). We did not estimate total annual storage emission using our equations due to the high variability of storage emission estimates for Swiss lakes (Fig. 5). The $10^{\varepsilon}$ value being higher than 200, this would have led to a major bias of emission values when backtransforming log-values.

\section{DISCUSSION}

\section{$\mathrm{CH}_{4}$ flux in late summer}

Higher $\mathrm{CH}_{4}$ concentrations in the surface water of central and western European lakes than in Fennoscandia have been reported in previous studies based on measurements in some of the same lakes as we examined in this study (Schilder et al. 2013; Rinta et al. 2015). Therefore, we also expected to find higher diffusive fluxes from central European lakes than from boreal lakes in our analysis. Using standardized measurements in late summer, we were able to confirm that both the measured daily diffusive and ebullitive flux were significantly higher in the central European lakes than in the boreal lakes (Fig. 2).

The factors responsible for the observed differences between the regions are difficult to identify since several environmental variables recognized as important for lacustrine $\mathrm{CH}_{4}$ emissions in earlier studies, such as temperatures (Liikanen et al., 2002; Marotta et al., 2014; Yvon-Durocher et al., 2014) and nutrient concentrations (Juutinen et al., 2009; Schrier-Uijl et al., 2010; Rasilo et al., 2014; Yang et al., 2015), but also geology and land use differ significantly between the regions (Tab. 1). Some of the reasons for the higher $\mathrm{CH}_{4}$ concentrations in the surface water of central European lakes compared to those in the boreal lakes are discussed by Rinta et al. (2015), and these arguments can also be extended to explain higher diffusive and ebullitive flux in the central European lakes. In short, higher $\mathrm{CH}_{4}$ production in the littoral zone is likely in the central European lakes due to warmer in situ temperature and more suitable substrates for methanogenesis (Duc et al., 2010). Lateral transport of $\mathrm{CH}_{4}$ from the littoral zone might be an important process in small central European lakes, as indicated by the $\mathrm{CH}_{4}$ concentrations and stable carbon isotopic composition $\left(\delta^{13} \mathrm{C}\right)$ profiles in the water column reported by Rinta et al. (2015), and may provide a source for high diffusive fluxes in the pelagic zone as well (Hofmann, 2013). The quality of the organic matter (OM) in the central European lakes may be more suitable for methanogenesis than in the boreal lakes, since autochthonous OM tends to be a better substrate for methanogenesis than OM of terrestrial origin (Duc et al., 2010; West et al., 2012; Guillemette et al., 2013). In-lake primary production is expected to be higher in the central European lakes due to the higher nutrient inputs from nonforested catchments dominated by arable land, pastures, and alpine grasslands often used for seasonal summer pasturing than from the more forested catchments in the boreal regions (Tab. 1). Furthermore, humic substances and acid conditions have been observed to inhibit methanogenic activity in lake sediments (Casper et al., 2003). The boreal lakes of our study are located in forest-dominated landscapes, and the water of these lakes is characterized by higher concentrations of DOC and lower $\mathrm{pH}$ than in central European lakes (Tab. 1).

Besides higher temperatures and more suitable substrate for methanogenesis, higher $\mathrm{CH}_{4}$ emissions from the central European lakes might also be related to differences in landscape structure. Six times higher estimates of logaverage daily diffusive flux values in the central European

Tab. 3. Regression equations for diffusive, ebullitive, and storage $\mathrm{CH}_{4}$ emission $\left(\mathrm{g} \mathrm{Clake}^{-1}\right.$ year $\left.{ }^{-1}\right)$ as a function of lake area $\left(\mathrm{m}^{2}\right)$ based on the daily flux estimates of this study.

\begin{tabular}{llcl} 
& Equation & P & $\mathbb{R}^{2}$ \\
Boreal & & & \\
$\log _{10}$ (diffusion) & & 0.000001 & 0.80 \\
$\log _{10}$ (ebullition) & $1.0258 * \log _{10}$ (lake area) -0.4739 & 0.001 & 0.64 \\
$\log _{10}$ (storage) & $0.9974 * \log _{10}$ (lake area) -0.4809 & 0.1 & 0.14 \\
\hline Central European & $8.1026-1.0335 * \log _{10}$ (lake area) & & \\
$\log _{10}$ (diffusion) & & 0.00002 & 0.48 \\
$\log _{10}$ (ebullition) & $0.8981 * \log _{10}$ (lake area) +1.1317 & 0.06 & 0.13 \\
$\log _{10}$ (storage) & $0.6392 * \log _{10}$ (lake area) +2.2962 & 0.006 & 0.24 \\
\hline
\end{tabular}

${ }^{\circ}$ Diffusion assumed to be relevant only during open-water season; " ebullition assumed to be relevant during half of the year, zero values excluded. 
lakes than for the boreal lakes cannot only be explained by differences in the $\mathrm{CH}_{4}$ concentrations in the surface water. Based on the model used to calculate diffusive flux into the floating chamber (see Methods), the observed flux values are only possible if the gas exchange rates at the water-atmosphere boundary of the central European lakes are also higher (Bade, 2009). This is supported by the significantly higher $k$ values in the central European lakes $(\mathrm{P}=0.04)$ (Fig. 4b). In our data set, higher wind-induced turbulence in the surface waters of the central European lakes cannot be explained by lake size (Schilder et al., 2013; Vachon and Prairie, 2013) since no significant difference in lake areas between the regions was observed. However, the central European lakes are mainly located in open landscape, whereas most of our boreal lakes are

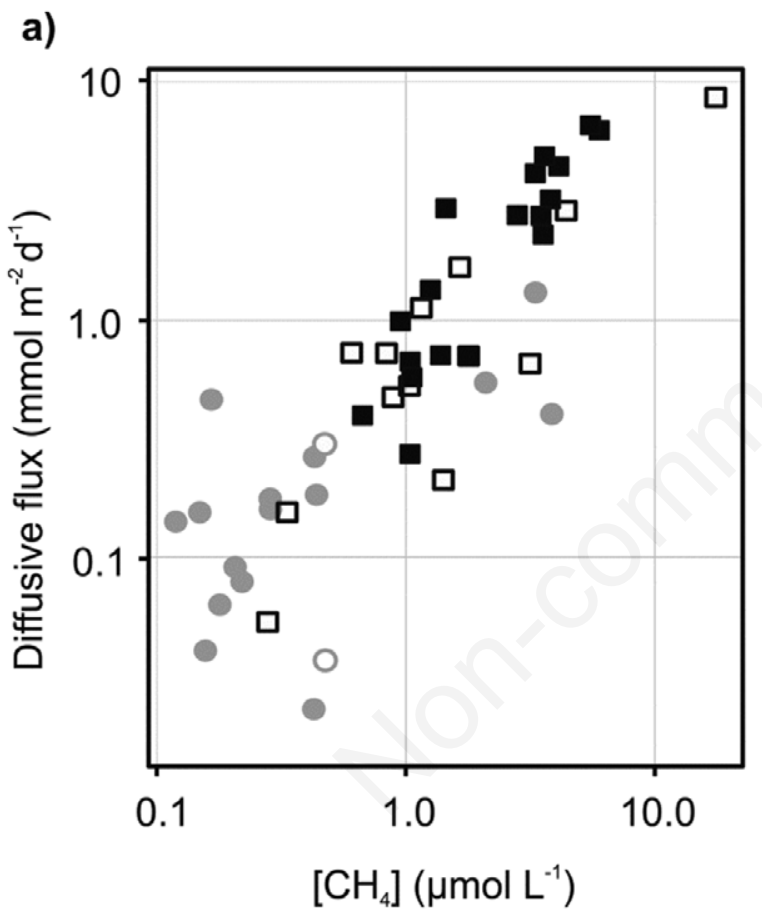

sheltered by forests, which may have led to higher windinduced turbulence in the surface water of the central European lakes (Markfort et al., 2010) (Tab. 1). Unfortunately, systematic differences in wind speeds near lake surfaces cannot be detected by the wind speed estimates at $10 \mathrm{~m}$ height obtained from meteorological monitoring networks.

\section{Environmental variables affecting $\mathrm{CH}_{4}$ flux in late summer}

Within the regions, no significant relationships between daily diffusive or ebullitive fluxes and variables related to temperature and nutrients were found (Tab. 2). Similarly, the relationships to morphological parameters (e.g., lake area, maximum depth, relative depth), which

b)

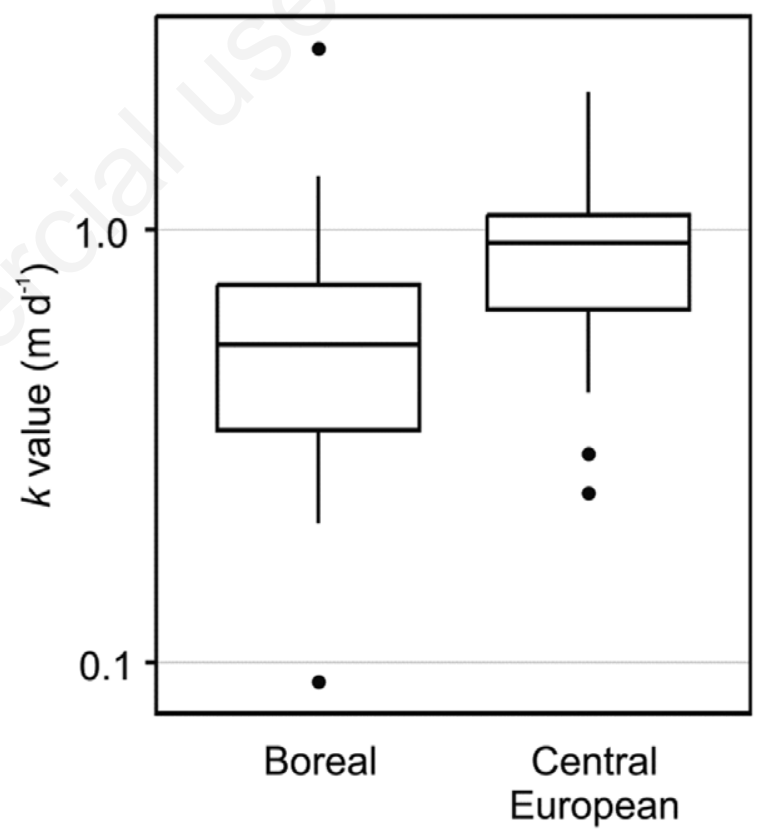

\section{- Boreal \\ - Central European \\ - Diffusive flux measured \\ 口 Diffusive flux estimated}

Fig. 4 a) Zone-weighted average diffusive flux plotted against $\mathrm{CH}_{4}$ concentration $\left(\left[\mathrm{CH}_{4}\right]\right)$ in the surface water $\left(\mathrm{P}=0.02, \mathrm{R}^{2}=0.33\right.$ and $\mathrm{P}<0.0001, \mathrm{R}^{2}=0.76$, for boreal and central European lakes, respectively). Open symbols indicate lakes where separation of diffusive and ebullitive flux was not possible in all zones and diffusive flux was estimated based on diffusive flux in the other zone or surface water $\left[\mathrm{CH}_{4}\right]$ and wind speed (see Methods for details). b) $k$ values representing zone-weighted lake averages for chambers having received diffusive flux only. Whiskers of the boxplots show data points less than 1.5 times the interquartile range from the box, circles indicate more extreme data points. 
have been recognized as one of the most important controls of the open-water $\mathrm{CH}_{4}$ emissions in lakes in the boreal regions and in northern temperate regions in North America (Bastviken et al., 2004; Juutinen et al., 2009; Kankaala et al., 2013; Rasilo et al., 2014), were not significant.

However, the absence of significant relationships between diffusive or ebullitive flux and environmental variables can be explained by the relatively short exposition of flux chambers (ca. $6 \mathrm{~h}$ ) in our study. Ebullition from lakes is characterized by large temporal and spatial variability (Mattson and Likens, 1990; Wik et al., 2013, 2016a). Therefore, our ebullition measurements may not have adequately captured regional patterns of betweenlake variability in ebullition, as is also evident in our data set in the form of very variable ebullition estimates within and between lakes (Fig. 3). Many floating chambers on lakes where no ebullition was detected during the six-hour measurement would likely have received some ebullition during a longer measurement period. Similarly, diffusive flux rates can be strongly impacted by variations in wind speed and water turbulence (Cole and Caraco, 1998; Bade, 2009). When $\mathrm{CH}_{4}$ concentrations in the surface water are examined instead of the measured diffusive flux estimates, relationships to morphometric variables are stronger in the boreal lakes (Tab. 2). In line with earlier studies (Bastviken et al., 2004; Kankaala et al., 2013), $\mathrm{CH}_{4}$ concentration in the boreal lakes of our data set are related to lake area and maximum depth (Fig. 2, Tab. 2). However, in the central European lakes the relationships between morphometric variables and $\mathrm{CH}_{4}$ concentration in the surface water are not evident (Fig. 2, Tab. 2), although they would have been significant without FDR correction for testing multiple relationships. The weaker relationship between lake area and $\mathrm{CH}_{4}$ concentrations in the surface water in the central European lakes might be a consequence of higher wind exposure causing more efficient mixing in the surface waters (see above). Also, the smaller range of lake area covered by the central European lakes than by the boreal lakes in our data set (Fig. 2) or the lakes studied by Bastviken et al. (2004) may have obscured relationships between lake area and $\mathrm{CH}_{4}$ concentrations.

As expected, the storage flux estimates are controlled by the relative depth and the relative volume of the hypoxic water layer in both regions (Tab. 2). The correlation between storage flux and average TN concentration in the water column can be explained by the effects of stratification stability on both of these variables. Strong stratification in the water column promotes accumulation of both $\mathrm{CH}_{4}$ and nutrients in the hypolimnion, which leads to larger storage flux values and may lead to higher TN concentrations averaged over the water column. The apparent relationships between storage flux and mean annual air temperature can be explained by the lake size distribution in our data set. In the boreal region, most of the lakes with relatively large hypoxic water layer are located in Finland, with lower mean annual air temperatures than in southern and central Sweden, and in central Europe at low altitudes (Supplementary Tab. 1).

\section{Influence on lacustrine $\mathrm{CH}_{4}$ emission estimates from Switzerland}

To examine how relevant the higher observed flux estimates from central European lakes are for estimating regional emissions, we compared, as an example, total annual emission values from small Swiss lakes estimated based on the original area-dependent regression equations by Bastviken et al. (2004) and those estimated following the procedure used in the Swiss $\mathrm{CH}_{4}$ inventory (Hiller et $a l ., 2014)$ with those calculated using the relationships between lake area and $\mathrm{CH}_{4}$ emissions based on our measurements in 30 central European lakes.

The comparison shows that estimates based on the equations developed mainly in northern European and North American lakes (Bastviken et al., 2004), and even those previously modified for Swiss conditions (Hiller et al., 2014), might underestimate the emissions from small central European lakes. Total annual diffusive emission from small Swiss lakes using the modified regression equations based on our measurements are estimated to be 5.7 times the value derived from the relationships by Bastviken et al. (2004) and 1.9 times the value estimated based on the relationships used by Hiller et al. (2014). Total annual ebullitive emission using our modified regression equations are 1.4 times the value estimated based on the equations by Bastviken et al. (2004) but similar to the value derived from the relationships used Hiller et al. (2014). For these calculations, we follow Hiller et al. (2014) in assuming that ebullition occurs only during the warmest half of the year and is not a relevant process in subalpine and alpine lakes due to their low organic accumulation rates. However, we observed high ebullitive fluxes also in small high-altitude lakes. In five out of eight lakes situated higher than 1500 $\mathrm{m}$ asl, ebullitive fluxes higher than $2 \mathrm{mmol} \mathrm{m}^{-2}$ day $^{-1}$ were measured in the shallow zone (Fig. 3). This indicates that the ebullition should be also included in estimates of total emissions of subalpine lakes surrounded by seasonal summer pastures or other agricultural activities, which may result in high sedimentation of organic matter in the lakes. Similarly, a recent study indicates that ebullitive flux in small Swiss lowland lakes can be significant even during the winter months (Schilder et al., 2016).

Annual emission estimates per lake as estimated by Bastviken et al. (2004), Hiller et al. (2014), and this study are sensitive to several assumptions regarding the annual variability of flux. First, ice-cover length is critical for extrapolating diffusive flux values measured during openwater season to annual flux. Bastviken et al. (2004) assumed 90-150 days of ice cover for northern European 
and North American lakes, when no diffusive flux occurred. For the comparison presented here, we used a rough estimate of six months of ice-cover in lakes located above 1500 $m$ asl but these estimates could be refined if more accurate data on ice-cover length in different altitudes would be available. Second, the extrapolation of our estimations of daily diffusive or ebullitive flux to annual flux assumes that measurements during a single day in late summer are representative for daily flux during the entire year. Diurnal variations in $\mathrm{CH}_{4}$ fluxes from the lake surface to the atmos- a)

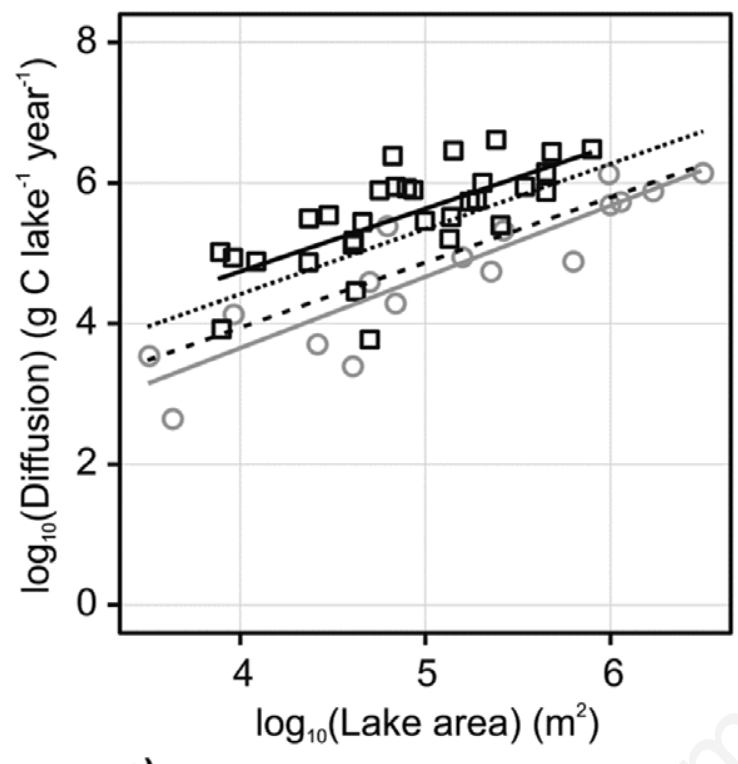

c)

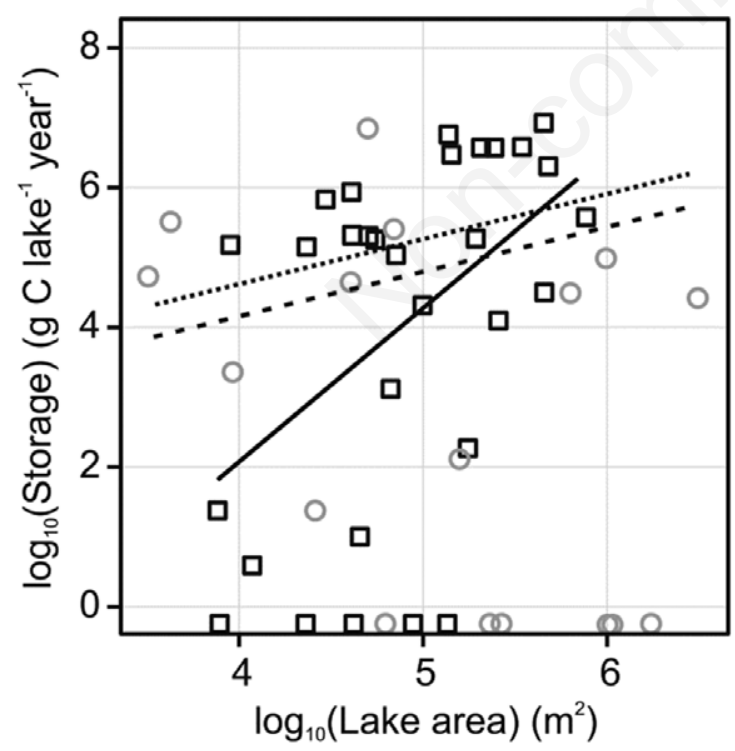

b)

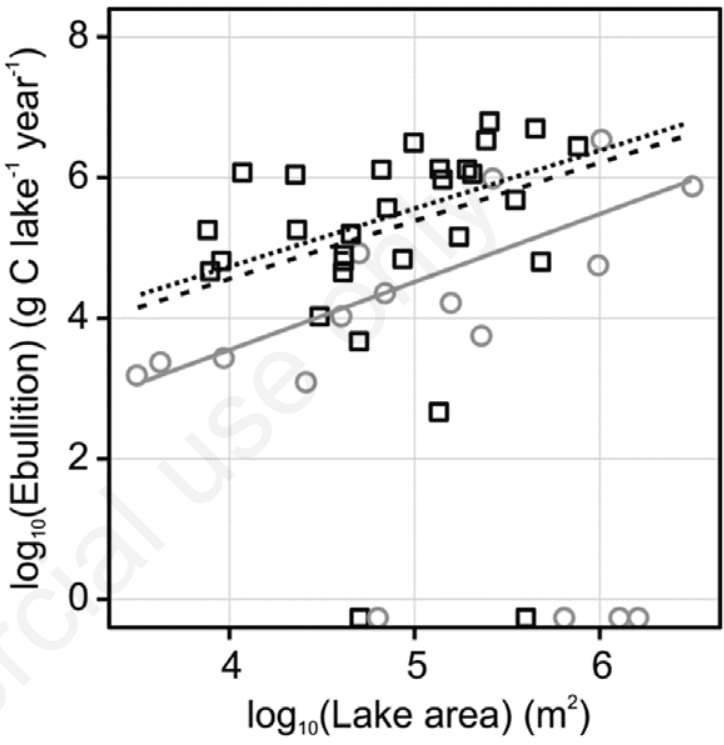

○ Boreal

口 Central European

\section{Regression lines}

- This study, boreal

This study, central European

- - B Bastviken et al. 2004

Hiller et al. 2014

Fig. 5 a) Diffusive $\mathrm{CH}_{4}$ emission assuming ice-free conditions during 215 days for Finnish lakes, 255 days for Swedish lakes, and during 182.5 days above $1500 \mathrm{~m}$ asl and during 365 days below $1500 \mathrm{~m}$ asl for central European lakes, b) ebullitive, and c) storage emission relative to lake area. Values on the $\mathrm{x}$-axis represent zero values. Where significant, linear regression lines for the boreal lakes and central European lakes are provided. For ebullition in c, zero values were not included in the regression equations. Additionally, the linear regression lines used by Bastviken et al. (2004) and Hiller et al. (2014) are indicated. Bastviken et al. (2004): diffusion=10 ${ }^{0.234}$

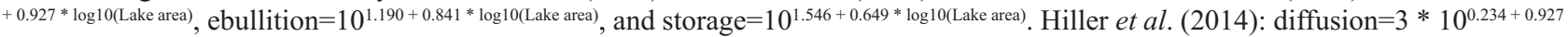

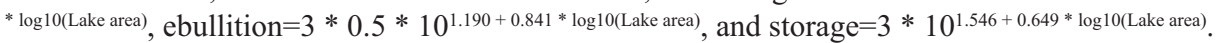


phere have been observed in several surveys (Keller and Stallard, 1994; Podgrajsek et al., 2014; Natchimuthu et al., 2014), and many studies have reported higher fluxes during summer than in other seasons (Casper et al., 2000; Martinez and Anderson, 2013), presumably due to higher temperature and in-lake productivity. In addition, high fluxes during ice thaw in spring, as a result of accumulation of $\mathrm{CH}_{4}$ under the ice, have been observed in several studies (Michmerhuizen et al., 1996; Karlsson et al., 2013; Miettinen et al., 2015). However, due to a general lack of studies describing diurnal and seasonal variations in $\mathrm{CH}_{4}$ flux from a wide range of lakes, it is presently not possible to use correction factors for our measurements during the morning-afternoon period and in late summer to make them more representative for daily or annual mean values.

Nevertheless, our regression equations are methodologically comparable with those of Bastviken et al. (2004) and hence able to show relative differences between annual diffusive and ebullitive emission estimates based on the earlier and our modified relationships between lake surface area and $\mathrm{CH}_{4}$ emissions. The comparability of our flux measurements with those reviewed by Bastviken et al. (2004) is strongly supported by the very similar relationship between lake area and diffusive and ebullitive emissions calculated for boreal lakes in our data set and the mainly boreal and northern temperate lakes presented by Bastviken et al. (2004) (Fig. 5). Our regression equations based on the measurements in boreal lakes in late summer even return lower annual diffusive emission per lake than based on the data of Bastviken et al. (2004), which indicates that our late summer measurements do not systematically overestimate the mean daily fluxes during open-water season compared to measurements reviewed by Bastviken et al. (2004). Our example on emissions from small Swiss lakes confirms the order of magnitude of correction factors used in the Swiss $\mathrm{CH}_{4}$ inventory (Hiller et al., 2014). However, our estimates also suggest that the total annual emissions from Swiss lakes might be even higher than estimated in the inventory.

\section{CONCLUSIONS}

In this study, we quantified open-water $\mathrm{CH}_{4}$ emissions using standardized methods for small lakes in Sweden, Finland, Germany, the Netherlands, and Switzerland in late summer. The measurements demonstrate that average late summer diffusive flux is significantly higher in central European lakes than in boreal lakes as indicated by the six-fold higher log-average diffusive flux observed for central European lakes. This difference is even more pronounced for ebullitive flux, with a 27 times higher logaverage flux recorded for central European lakes, although due to the high temporal variability of ebullition in lakes and the short measurement period in our campaign we are likely underestimating ebullitive flux in our study. In contrast to earlier studies, we did not find significant relationships between diffusive or ebullitive flux and environmental variables. Storage flux was similar between the regions and was related to the relative depth of the lake basin, relative volume of the hypoxic water layer, and average TN concentration in the water column.

Despite the many uncertainties still involved in the upscaling of open-water $\mathrm{CH}_{4}$ emissions at regional scales, we were able to show that the significantly higher diffusive and ebullitive flux values observed in the central European lakes than in the boreal lakes of this study are relevant for inventories of lacustrine $\mathrm{CH}_{4}$ emissions in central European regions. As suggested by Hiller et al. (2014), modifications are needed for regression equations developed in northern European and North American regions before they can be used in central European conditions. Especially, detailed seasonal studies of both diffusive and ebullition flux, for the latter including observations during winter ice cover and at different elevations, are therefore necessary to further refine $\mathrm{CH}_{4}$ emission rates from small central European lakes.

\section{ACKNOWLEDGMENTS}

We thank Willi Tanner for assistance in the field and various authorities and private persons for permits for accessing lakes and using their boats. Climate data was provided by Finnish Meteorological Institute, Swedish Meteorological and Hydrological Institute, Deutscher Wetterdienst, Royal Netherlands Meteorological Institute, and Swiss Federal Office of Meteorology and Climatology. VECTOR25 data was used in accordance with School license of Swiss Federal Office of Topography. The research leading to these results has received funding from the European Research Council under the European Union's Seventh Framework Programme (FP/2007-2013) / ERC Grant Agreement n. 239858 (RECONMET). Work in Sweden was partly supported by the Swedish Research Council VR. The Skogaryd Research Catchment is a part of the SITES network.

\section{REFERENCES}

Bade DL, 2009. Gas Exchange at the Air - Water Interface, p. 70-78. In: G.E. Likens (ed.), Encyclopedia of inland waters. Academic Press, London.

Bastviken D, Cole JJ, Pace ML, Tranvik LJ, 2004. Methane emissions from lakes: Dependence of lake characteristics, two regional assessments, and a global estimate. Global Biogeochem. Cycles 18:1-12.

Bastviken D, Santoro AL, Marotta H, Pinho LQ, Calheiros DF, Crill PM, Enrich-Prast A, 2010. Methane emissions from Pantanal, South America, during the low water season: toward more comprehensive sampling. Environ. Sci. Technol. 44:5450-5455. 
Bastviken D, Tranvik LJ, Downing JA, Crill PM, Enrich-Prast A, 2011. Freshwater methane emissions offset the continental carbon sink. Science 50:331.

Benjamini Y, Hochberg Y, 1995. Controlling the false discovery rate: a practical and powerful approach to multiple testing. J. R. Stat. Soc. Ser. B 57:289-300.

Casper P, Chim Chan O, Furtado ALS, Adams DD, 2003. Methane in an acidic bog lake: The influence of peat in the catchment on the biogeochemistry of methane. Aquat. Sci. 65:36-46.

Casper P, Maberly SC, Hall GH, Finlay BJ, 2000. Fluxes of methane and carbon dioxide from a small productive lake to the atmosphere. Biogeochemistry 49:1-19.

Ciais P, Dolman AJ, Bombelli A, Duren R, Peregon A, Rayner PJ, Miller C, Gobron N, Kinderman G, Marland G, Gruber N, Chevallier F, Andres RJ, Balsamo G, Bopp L, Bréon FM, Broquet G, Dargaville R, Battin TJ, Borges A, Bovensmann H, Buchwitz M, Butler J, Canadell JG, Cook RB, DeFries R, Engelen R, Gurney KR, Heinze C, Heimann M, Held A, Henry M, Law B, Luyssaert S, Miller J, Moriyama T, Moulin C, Myneni RB, Nussli C, Obersteiner M, Ojima D, Pan Y, Paris J-D, Piao SL, Poulter B, Plummer S, Quegan S, Raymond P, Reichstein M, Rivier L, Sabine C, Schimel D, Tarasova O, Valentini R, Wang R, van der Werf G, Wickland D, Williams M, Zehner C, 2014. Current systematic carbon-cycle observations and the need for implementing a policy-relevant carbon observing system. Biogeosciences 11:3547-3602.

Cole JJ, Caraco NF, 1998. Atmospheric exchange of carbon dioxide in a low-wind oligotrophic lake measured by the addition of $\mathrm{SF}_{6}$. Limnol. Oceanogr. 43:647-656.

Duc NT, Crill PM, Bastviken D, 2010. Implications of temperature and sediment characteristics on methane formation and oxidation in lake sediments. Biogeochemistry 100:185-196.

Ducharme-Riel V, Vachon D, del Giorgio PA, Prairie YT, 2015. The Relative Contribution of Winter Under-Ice and Summer Hypolimnetic $\mathrm{CO}_{2}$ Accumulation to the Annual $\mathrm{CO}_{2}$ Emissions from Northern Lakes. Ecosystems 18:547-559.

Encinas Fernández J, Peeters F, Hofmann H, 2014. Importance of the autumn overturn and anoxic conditions in the hypolimnion for the annual methane emissions from a temperate lake. Environ. Sci. Technol. 48:7297-7304.

European Environmental Agency, 2007. CLC2006 technical guidelines. European Environmental Agency, Copenhagen: $66 \mathrm{pp}$.

Guillemette F, McCallister SL, del Giorgio PA, 2013. Differentiating the degradation dynamics of algal and terrestrial carbon within complex natural dissolved organic carbon in temperate lakes. J. Geophys. Res. Biogeosciences. 118:963-973.

Guthruf J, Guthruf-Seiler K, Zeh M, 1999. [Kleinseen im Kanton Bern].[Book in German]. Amt für Gewässerschutz und Abfallwirtschaft des Kantons Bern, Bern: 230 pp.

Hiller RV, Bretscher D, Del Sontro TS, Diem T, Eugster W, Henneberger R, Hobi S, Hodson E, Imer D, Kreuzer M, Künzle T, Merbold L, Niklaus PA, Rihm B, Schellenberger A, Schroth MH, Schubert CJ, Siegrist H, Stieger J, Buchmann $\mathrm{N}$, Brunner D, 2014. Anthropogenic and natural methane fluxes in Switzerland synthesized within a spatially-explicit inventory. Biogeosciences 10:15181-15224.

Hofmann H, 2013. Spatiotemporal distribution patterns of dissolved methane in lakes: How accurate are the current estimations of the diffusive flux path? Geophys. Res. Lett. 40:2779-2784.
Holgerson MA, Raymond PA, 2016. Large contribution to inland water $\mathrm{CO}_{2}$ and $\mathrm{CH}_{4}$ emissions from very small ponds. Nature Geosci. 9:222-226.

Huotari J, Ojala A, Peltomaa E, Pumpanen J, Hari P, Vesala T, 2009. Temporal variations in surface water $\mathrm{CO}_{2}$ concentration in a boreal humic lake based on high-frequency measurements. Boreal Envrironment Res. 14:48-60.

Huttunen JT, Alm J, Liikanen A, Juutinen S, Larmola T, Hammar T, Silvola J, Martikainen PJ, 2003. Fluxes of methane, carbon dioxide and nitrous oxide in boreal lakes and potential anthropogenic effects on the aquatic greenhouse gas emissions. Chemosphere 52:609-621.

Juutinen S, Alm J, Larmola T, Huttunen JT, Morero M, Martikainen PJ, Silvola J, 2003. Major implication of the littoral zone for methane release from boreal lakes. Global Biogeochem. Cycles 17:1-11.

Juutinen S, Rantakari M, Kortelainen PL, Huttunen JT, Larmola T, Alm J, Silvola J, Martikainen PJ, 2009. Methane dynamics in different boreal lake types. Biogeosciences 6:209-223.

Kankaala P, Huotari J, Tulonen T, Ojala A, 2013. Lake-size dependent physical forcing drives carbon dioxide and methane effluxes from lakes in a boreal landscape. Limnol. Oceanogr. Oceanogr. 58:1915-1930.

Karlsson J, Giesler R, Persson J, Lundin E, 2013. High emission of carbon dioxide and methane during ice thaw in high latitude lakes. Geophys. Res. Lett. 40:1123-1127.

Keller M, Stallard RF, 1994. Methane emission by bubbling from Gatun Lake, Panama. J. Geophys. Res. 99:8307-8319.

Kirschke S, Bousquet P, Ciais P, Saunois M, Canadell JG, Dlugokencky EJ, Bergamaschi P, Bergmann D, Blake DR, Bruhwiler L, Cameron-Smith P, Castaldi S, Chevallier F, Feng L, Fraser A, Heimann M, Hodson EL, Houweling S, Josse B, Fraser PJ, Krummel PB, Lamarque J-F, Langenfelds RL, Le Quéré C, Naik V, O’Doherty S, Palmer PI, Pison I, Plummer D, Poulter B, Prinn RG, Rigby M, Ringeval B, Santini M, Schmidt M, Shindell DT, Simpson IJ, Spahni R, Steele LP, Strode SA, Sudo K, Szopa S, van der Werf GR, Voulgarakis A, van Weele M, Weiss RF, Williams JE, Zeng G, 2013. Three decades of global methane sources and sinks. Nat. Geosci. 6:813-823.

Korhonen J, 2005. Ice conditions in lakes and rivers in Finland. [Book in Finnish]. Edita Prima Oy, Helsinki: 145 pp.

Liikanen A, Murtoniemi T, Tanskanen H, Väisänen T, Martikainen PJ, 2002. Effects of temperature and oxygen availability on greenhouse gas and nutrient dynamics in sediment of a eutrophic mid-boreal lake. Biogeochemistry 59:269-286.

Loulergue L, Schilt A, Spahni R, Masson-Delmotte V, Blunier T, Lemieux B, Barnola J-M, Raynaud D, Stocker TF, Chappellaz $\mathrm{J}, 2008$. Orbital and millennial-scale features of atmospheric $\mathrm{CH}_{4}$ over the past 800,000 years. Nature 453:383-6.

Markfort CD, Perez ALS, Thill JW, Jaster DA, Porté-Agel F, Stefan HG, 2010. Wind sheltering of a lake by a tree canopy or bluff topography. Water Resour. Res. 46:1-13.

Marotta H, Pinho L, Gudasz C, Bastviken D, Tranvik LJ, 2014. Greenhouse gas production in low-latitude lake sediments responds strongly to warming. Nat. Clim. Chang. 4:467-470.

Martinez D, Anderson MA, 2013. Methane production and ebullition in a shallow, artificially aerated, eutrophic temperate lake (Lake Elsinore, CA). Sci. Total Environ. 454-455:457-465.

Mattson MD, Likens GE, 1990. Air pressure and methane fluxes. Nature 347:718-719.

McAuliffe CD, 1971. GC determination of solutes by multiple phase equilibration. Chem. Technol. 1:46-51. 
Michmerhuizen CM, Striegl RG, McDonald ME, 1996. Potential methane emission from lakes following ice melt. Limnol. Oceanogr. 41:985-991.

Miettinen H, Pumpanen J, Heiskanen JJ, Aaltonen H, Mammarella I, Ojala A, Levula J, Rantakari M, 2015. Towards a more comprehensive understanding of lacustrine greenhouse gas dynamics - two-year measurements of concentrations and fluxes of $\mathrm{CO}_{2}, \mathrm{CH}_{4}$ and $\mathrm{N}_{2} \mathrm{O}$ in a typical boreal lake surrounded by managed forests. Boreal Envrironment Res. 20:75-89.

Myhre G, Shindell D, Bréon F-M, Collins W, Fuglestvedt J, Huang J, Koch D, Lamarque J-F, Lee D, Mendoza B, Nakajima T, Robock A, Stephens G, Takemura T, Zhang H, 2013. Anthropogenic and Natural Radiative Forcing. p. 659-740. In: T.F. Stocker, D. Qin, G.-K. Plattner, M. Tignor, S.K. Allen, J. Boschung, A. Nauels, Y. Xia, V. Bex and P.M. Midgley (eds.), Climate Change 2013: The Physical Science Basis. Contribution of Working Group I to the Fifth Assessment Report of the Intergovernmental Panel on Climate Change. Cambridge University Press, Cambridge: $1535 \mathrm{pp}$.

Natchimuthu S, Panneer Selvam B, Bastviken D, 2014. Influence of weather variables on methane and carbon dioxide flux from a shallow pond. Biogeochemistry 119:403-413.

Newman MC, 1993. Regression analysis of log-transformed data statistical bias and its correction. Environ. Toxicol. Chem. 12:1129-1133.

Nippel T, Klingl T, 1998. Swiss Land Use in the European Context, Integration of Swiss Land Use Statistics with CORINNE Land Cover. Swiss Federal Statistical Office and Swiss Agency for the Environment, Neuchâtel: 43 pp.

Nisbet EG, Dlugokencky EJ, Bousquet P, 2014. Methane on the rise-again. Science 343:493-495.

Ortiz-Llorente MJ, Alvarez-Cobelas M, 2012. Comparison of biogenic methane emissions from unmanaged estuaries, lakes, oceans, rivers and wetlands. Atmos. Environ. 59:328-337.

Ouellet A, Lalonde K, Plouhinec J-B, Soumis N, Lucotte M, Gélinas Y, 2012. Assessing carbon dynamics in natural and perturbed boreal aquatic systems. J. Geophys. Res. 117:1-13.

Podgrajsek E, Sahlée E, Rutgersson A, 2014. Diurnal cycle of lake methane flux. Biogeosciences. 119:236-248.

R Core Team, 2013. R: a language and environment for statistical computing. The R Foundation for Statistical Computing, Vienna.

Rasilo T, Prairie YT, del Giorgio PA, 2014. Large-scale patterns in summer diffusive $\mathrm{CH}_{4}$ fluxes across boreal lakes, and contribution to diffusive $\mathrm{C}$ emissions. Glob. Chang. Biol. 21:1124-1139.

Rinta P, Bastviken D, van Hardenbroek M, Kankaala P, Leuenberger MC, Schilder J, Stötter T, Heiri O, 2015. An inter-regional assessment of concentrations and $\delta^{13} \mathrm{C}$ values of methane and dissolved inorganic carbon in small European lakes. Aquat. Sci. 77:667-680.

Saarnio S, Winiwarter W, Leitão J, 2009. Methane release from wetlands and watercourses in Europe. Atmos. Environ. 43: 1421-1429.

Schilder J, Bastviken D, van Hardenbroek M, Heiri O, 2016. Spatiotemporal patterns in methane flux and gas transfer velocity at low wind speeds: Implications for upscaling studies on small lakes. J. Geophys. Res. Biogeosciences. 121:1456-1467.
Schilder J, Bastviken D, van Hardenbroek M, Kankaala P, Rinta P, Stötter T, Heiri O, 2013. Spatial heterogeneity and lake morphology affect diffusive greenhouse gas emission estimates of lakes. Geophys. Res. Lett. 40:5752-5756.

Schrier-Uijl AP, Veraart AJ, Leffelaar PA, Berendse F, Veenendaal EM, 2011. Release of $\mathrm{CO}_{2}$ and $\mathrm{CH}_{4}$ from lakes and drainage ditches in temperate wetlands. Biogeochemistry. 102:265-279.

Schulze E-D, Ciais P, Luyssaert S, Schrumpf M, Janssens IA, Thiruchittampalam B, Theloke J, Saurat M, Bringezu S, Lelieveld J, Lohila A, Rebmann C, Jung M, Bastviken D, Abril G, Grassi G, Leip A, Freibauer A, Kutsch W, Don A, Nieschulze J, Börner A, Gash JH, Dolman AJ, 2010. The European carbon balance. Part 4: integration of carbon and other trace-gas fluxes. Glob. Chang. Biol. 16:1451-1469.

Stumm W, Morgan JJ, 1996. Aquatic chemistry: chemical equilibria and rates in natural waters, 3rd ed. John Wiley, New York: $1022 \mathrm{pp}$.

Swedish Meteorological and Hydrological Institute, 2014. [Is på sjöar och vattendrag].[Page in Swedish]. http://www.smhi.se/ klimatdata/hydrologi/is-pa-sjoar-och-vattendrag. Accessed 5.10.2014

Swiss Federal Office of Topography, 2007. VECTOR25 [Das digitale Landschaftsmodell der Schweiz].[Book in German]. Swiss Federal Office of Topography, Wabern: $31 \mathrm{pp}$.

Swiss Federal Office of Topography, 2005. DHM25 The digital height model of Switzerland. Swiss Federal Office of Topography, Wabern: $15 \mathrm{pp}$.

Vachon D, Prairie YT, 2013. The ecosystem size and shape dependence of gas transfer velocity versus wind speed relationships in lakes. Can. J. Fish. Aquat. Sci. 70:1757-1764.

Verpoorter C, Kutser T, Seekell DA, Tranvik LJ, 2014. A global inventory of lakes based on high-resolution satellite imagery. Geophys. Res. Lett. 41:6396-6402.

West WE, Coloso JJ, Jones SE, 2012. Effects of algal and terrestrial carbon on methane production rates and methanogen community structure in a temperate lake sediment. Freshwater Biol. 57:949-955.

Wetzel RG, 2001. Limnology Lake and River Ecosytems. Academic Press, San Diego: 1006 pp.

Wik M, Crill PM, Varner RK, Bastviken D, 2013. Multiyear measurements of ebullitive methane flux from three subarctic lakes. J. Geophys. Res. Biogeosciences. 118:13071321.

Wik M, Thornton BF, Bastviken D, Uhlbäck J, Crill PM, 2016a. Biased sampling of methane release from northern lakes: A problem for extrapolation. Geophysica doi: 10.1002/ 2015GL066501

Wik M, Varner RK, Walter Anthony K, MacIntyre S, Bastviken D, 2016b. Climate-sensitive northern lakes and ponds are critical components of methane release. Nature Geosci. 9:99-105.

Yang H, Andersen T, Dörsch P, Tominaga K, Thrane JE, Hessen DO, 2015. Greenhouse gas metabolism in Nordic boreal lakes. Biogeochemistry 126:211-225.

Yvon-Durocher G, Allen AP, Bastviken D, Conrad R, Gudasz C, St-Pierre A, Duc NT, del Giorgio PA, 2014. Methane fluxes show consistent temperature dependence across microbial to ecosystem scales. Nature 507:488-491. 